\title{
E-Learning Based on Video Presentations to Enhances Attitudes, Skills, and Pedagogical Knowledge of Prospective Teacher Students During the Covid-19 Pandemic
}

\author{
Wasilatul Murtafiah ${ }^{1 *}$, Ika Krisdiana ${ }^{2}$, Titin Masfingatin ${ }^{3}$, Vera Dewi Susanti ${ }^{4}$, \\ Reza Kusuma Setyansah ${ }^{5}$ \\ 1,2,3,4,5 Mathematics Education Department, Universitas PGRI Madiun, Indonesia \\ *e-mail: wasila.mathedu@unipma.ac.id
}

\begin{abstract}
This study aims to develop an e-learning tool based on video presentations to enhances attitudes, skills and pedagogical knowledges of prospective teacher students during the Covid-19 pandemic. This type of research is Research and Design $(R \& D)$ using the Plomp development model, which consists of 3 stages: a preliminary study, design, and assessment. Data collection was carried out through observation, device validation, distribution of response questionnaires, and assessment of student learning outcomes. The results of the data analysis show that at the preliminary study stage, it was found that there were still no devices that supported learning during the Covid-19 pandemic. At the stage of design was designed, including RPS, LMS Settings, and Video Presentations. At the assessment stage, it was found that all the tools developed had valid criteria, students gave a positive response to the small and broad trials respectively of $97.68 \%$; $98.32 \%$ so that the tools developed were included in practical criteria. The assessment of learning outcomes in the aspects of attitudes, skills, and knowledge had average completeness on the small and broad trials respectively of $82.92 \%$; $86.99 \%$ so that the equipment used was included in the effective criteria. Thus the device developed can be said to be feasible because it meets the criteria of validity, practicality, and effectiveness. The development of e-learning based on video presentations can be used to enhance attitudes, skills, and pedagogical knowledge of prospective mathematics teacher students.
\end{abstract}

Keywords: E-Learning, Presentation Video, Attitude, Skills, Pedagogical Knowledge

\section{Introduction}

The Covid-19 pandemic in mid-2020 that hit the whole world including Indonesia, caused significant changes in the world of education (Batubara \& Batubara, 2020; Buana, 2020; Yulia, 2020). The most affected is the implementation of education or the implementation of learning starting from the elementary, middle to high level (Dhawan, 2020; Kadafi et al., 2021; Subarkah \& Salim, 2021). There is an appeal from the Indonesian government to avoid physical distancing, so learning cannot be done face-to-face like before the Covid-19 pandemic. This is also in line with the Indonesian Minister of Education who stated that learning is carried out from home or through a rotating system (Dewantara \& Nurgiansah, 2020; Prawiyogi et al., 2020; Tamboto et al., 2021). Following up on this policy, there is a need for rapid adaptation to design learning to support learning from home or distance learning (Eryadini et al., 2020; Shah et al., 2020). As in tertiary institutions, lecturers must also respond quickly to current conditions by implementing distance learning (online). In several countries, online learning has become a solution to the problems of implementing learning during the Covid-19 pandemic (Ali, 2020; Baber, 2020; Basilaia \& Kvavadze, 2020). Online learning has emerged as an alternative to traditional learning during the Covid-19 pandemic and most first-time students have online classes (Baber, 2020). Universities or Colleges around the world are increasingly moving towards online learning or E-Learning (Ali, 2020; Yousfi et al., 2021).

However, there are still many challenges faced by lecturers in universities in implementing online learning, namely limitations in presenting material for various subjects

\footnotetext{
${ }^{*}$ Corresponding author.
}

Received April 03, 2021; Accepted May 29, 2021; Available online December 25, 2021

This is an open access article under the CC BY-SA license. Copyright $(2021$ by Author. Published by Universitas Pendidikan Ganesha 
with various characteristics (Irfan et al., 2020; Sadikin \& Hamidah, 2020; Yudiawan, 2020). The same thing was experienced by lecturers in the mathematics education study program at Universitas PGRI Madiun (UNIPMA). Lecturers still haven't maximized the use of e-learning. Lecturers have not made innovations in presenting the material. The materials uploaded on e-learning are also not the product of a lecturer. The materials taught in the UNIPMA mathematics education study program are subject matter that supports professional and pedagogical competence for prospective teacher students. These two competencies are important competences for prospective mathematics teachers (Ambussaidi \& Yang, 2019; Hillmayr et al., 2020; Sanusi et al., 2016). One of the subjects taught in the study program that prepares prospective mathematics teachers is introductory education. This subject is a subject that must be taken because it supports knowledge of pedagogic content which is very important for prospective teachers. Pedagogic content knowledge is currently developing into technology pedagogic content knowledge. Both of these knowledge are urgently needed by prospective teachers to prepare to become professional teachers in the future. However, most students feel bored with educational introductory material because according to them there is a lot of memorization material. This has an impact on the less than optimal student learning outcomes in the introductory material of education in terms of attitudes, skills and knowledge (Backfisch et al., 2020; Supriadi, 2020; S.-C. (Angel) Wu \& Chang, 2015).

Based on these problems, it is necessary to make learning innovations using elearning (Logan et al., 2021; W. Wu \& Plakhtii, 2021; Yaniawati, 2013). Innovation is also carried out by designing video presentations so that students are not bored and bored in taking introductory education lectures (Saiboon et al., 2021; Teng, 2019; Yendrita \& Syafitri, 2019). In addition to maximizing the use of features in e-learning, the design of the presentation video is carried out in accordance with the educational material to be taught. The use of video presentations in learning is expected to help students digest and understand the material taught during the Covid-19 pandemic (Batubara \& Batubara, 2020; Mpungose, 2021). Thus, it is important to design e-learning based on video presentations for prospective mathematics teacher students in an introductory education course which supports the attitudes, skills and pedagogical competences of prospective mathematics teacher students during the Covid-19 pandemic (Mayang \& Aslam, 2021; Prehanto et al., 2021). Several previous studies have been carried out regarding learning innovations using e-learning (Irfan et al., 2020; Sulistyaningsih et al., 2018). The challenges faced by lecturers in universities in carrying out learning during the Covid-19 pandemic (Cahyadi, 2020; Irfan et al., 2020). The results of these studies indicate that there is no learning innovation for prospective mathematics teacher students using e-learning based on video presentations in courses that support pedagogical competence, namely the introduction of education (Sulistyaningsih et al., 2018). Thus, this study aims to describe the development of e-learning based on video presentations for enhance attitudes, skills, and pedagogical knowledge of prospective mathematics teacher students during the Covid-19 pandemic. This research is important because there is still a lack of learning tools that can be applied during the Covid19 pandemic or learning tools that are applied online or blended.

\section{Method}

This research is Research and Design (R \& D) which aims to develop e-learning based on video presentations for enhances attitudes, skills, and pedagogical knowledge of prospective mathematics teacher student in introductory education during the Covid-19 pandemic. The research was carried out on semester 3 students in the mathematics education study program of the Teaching Faculty of Education, PGRI Madiun University who are programming the introductory education course for the 2020/2021 academic year. The learning design in this study uses the Plomp development model with 3 stages (Plomp, 2010). The first stage, the preliminary research stage which aims to identify the needs needed for the development of video-based e-learning for student mathematics teacher candidates in introductory education courses during the Covid-19 pandemic. The second 
stage is the prototyping stage, where video-based e-learning designs and designs are carried out for prospective mathematics teacher students in introductory education courses during the Covid-19 pandemic. The third stage is the assessment stage, testing the instrument in small groups and large group. At the assessment stage, a video presentationbased e-learning tool will be obtained which includes: RPS, LMS settings and video presentations that meet the valid, practical and effective criteria.

The validity of e-learning tools based on video presentations (RPS, LMS Settings, and Video Presentations) are validated by experts using validation instruments. The elearning tool based on the video presentation is said to be valid if the validator gives an assessment of each component in the instrument at least good criteria Meilantifa \& Budiarto, 2018). The practicality of e-learning tools based on video presentations is seen from the student response questionnaire to the application of video presentation-based e-learning tools. E-learning tools based on video presentations are said to be practical if students give a positive response of more than $70 \%$ (Trilaksono, Darmadi, \& Murtafiah, 2018). The effectiveness of e-learning tools based on video presentations is seen from student learning outcomes based on the assessment of attitudes, skills and knowledge instruments. Elearning tools based on video presentations are said to be effective if the student learning outcomes $\geq 75$ are more than $80 \%$ (Hobri, 2010). The development of an e-learning tool based on video presentations is said to be feasible if it meets the criteria of validity, practicality and effectiveness.

\section{Result and Discussion}

\section{Results}

The development of e-learning based on video presentations is carried out based on the development stages according to Plomp (2010) which include: (1) the preliminary research stage, (2) the prototyping stage, and (3) the assessment stage. The results of the development in this study can be described for each stage as follows. At the preliminary research stage, problem identification and needs analysis is carried out for the curriculum used, the applied learning, and existing learning tools. Based on the applicable curriculum in the mathematics education study program at PGRI Madiun University, the introductory education course is one of the courses that equip students with pedagogical knowledge. Learning outcomes in the introductory education course are students who are able to explain the nature of human beings and their development, understanding and elements of education, educational factors, educational theories, educational foundations and principles and their application, estimation and anticipation of future society, definition, function and type of educational environment, educational streams, educational problems, the national education system, education and development and the role of the family, government and society in education. The written achievements have not shown any achievements that include the realms of knowledge, attitudes and skills of students through learning in introductory education courses. The learning that has been carried out so far is learning that has been carried out entirely offline. Online learning has never been done. Seeing the current conditions, namely the Covid-19 pandemic, learning is done from home, so inevitably learning is done online. Online learning can be done using an e-learning platform. To apply a learning tool, a device is needed. The existing learning tools are face-to-face/offline learning tools. There are no learning tools specifically designed to implement online learning. For that, we need learning tools specifically designed for online learning.

At prototyping stage, video presentation-based e-learning tools are designed which include: (1) semester course plans (RPS), (2) learning management system (LMS) settings, and (3) video presentations. The design of the four devices is described as follows. The semester course plan is designed with components consisting of course descriptions, course learning outcomes, final abilities planned to achieve learning outcomes, study materials (learning materials), learning methods, learning experiences, time allocation, assessment, learning resources. LMS settings are carried out in UNIPMA e-learning (e-LMA) by naming introductory education courses as in Figure 1. 


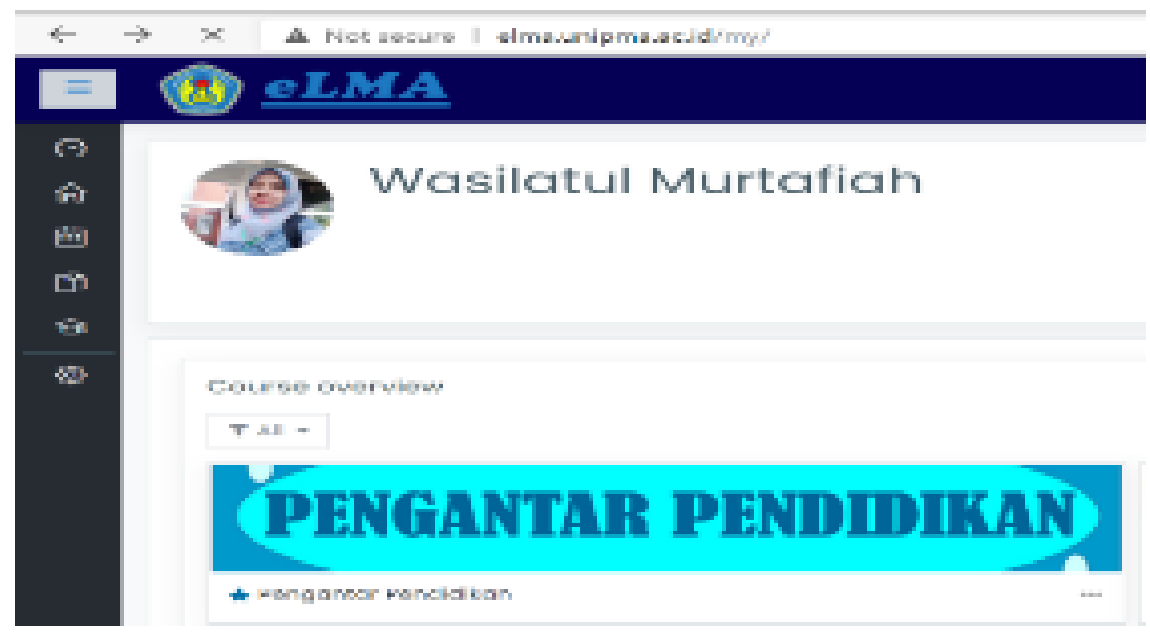

Figure 1. Introductory Education Course in e-LMA

After compiling the home for the introductory education course, then making the settings according to the RPS that has been designed. LMS settings are arranged starting from course profiles, welcome greetings, learning outcomes, lecturers and tutors, meetings 1-6, UTS, meetings 8-15, UAS. The settings for each meeting at the LMS are designed with attendance activities, listening to video material and discussions on the forum. At certain meetings it is added with the activity of collecting assignments and tests as in Figure 2.

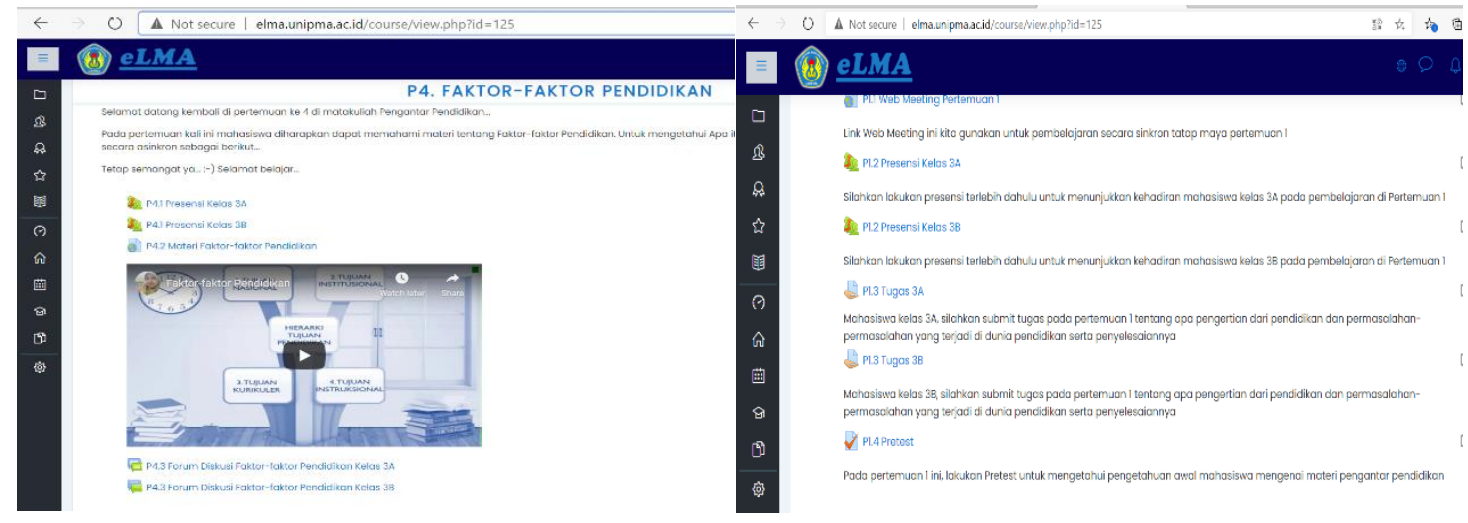

Figure 2. Settings for each Meeting on the e-LMA

In several meetings, in addition to attendance activities, presentation of material through video and discussion forums, LMS settings in e-LMA were also added with test activities and assignments. Video presentation is a video designed to convey ideas as a substitute for presentations that are done in person/face to face. Videos are designed using video editing applications which include: bendicam, filmora, kinemaster, free cam screen recorder and power point on office mix. One of the videos that has been designed as in Figure 3.

The presentation video is designed to deliver material in an introductory education course. The presentation video will then be uploaded/embeded on the LMS. To reduce file capacity in the LMS, the designed presentation video is uploaded first on www.YouTube.com. At the assessment stage, an assessment of the tools being developed is carried out, namely RPS, LMS settings, and Video Presentations. The assessment tools developed include validity, practicality and effectiveness. The validity assessment is carried out by a validator who is an expert / expert. Practicality and effectiveness assessments were carried out after the limited trials and extensive trials were carried out. Limited trials were conducted on 5 students, while extensive trials were conducted on 41 student teacher candidates in the UNIPMA mathematics education study program. The following describes 
the validity, practicality and effectiveness of e-learning tools based on video presentations in the introductory education course.

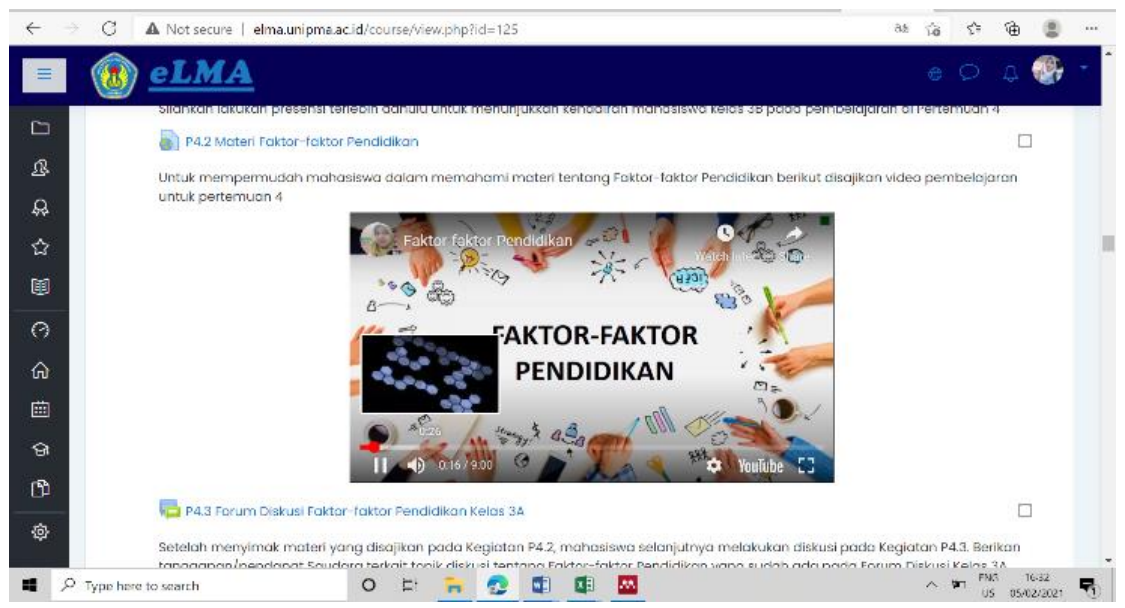

Figure 3. Video Presentation on Educational Factors Material

The validity of the e-learning tool based on video presentations in the introductory education course was carried out by 5 validators consisting of 1 doctorate in the field of learning technology and 2 doctors in the field of mathematics education from Universitas PGRI MADIUN and 1 each doctor in mathematics education from Universitas PGRI Semarang and Universitas Muhammadiyah Purworejo. To find out the validity of the RPS for introductory education, an assessment was carried out on aspects including: learning objectives, learning activities, language, and RPS systematics. The aspect of learning objectives consist of: (1) The final ability is planned according to learning outcomes, (2) Indicators according to the planned final ability, (3) Indicators are formulated in a clear, specific, and operational manner so that they can be measured, (4) Indicators according to the time allocation designed. The aspect of learning activities consist of: (1) The activities of lecturers and students are formulated clearly and in detail, (2) Learning activities according to the chosen method (using e-learning), (3) Each learning activity contains sufficient time allocation, (4) The timing of each meeting is clearly stated. The aspect of language consist of: (1) Use language that is in accordance with the rules of Indonesian that is good and correct, (2) The language used in SAP does not give rise to double meanings/interpretations. The aspect of RPS systematics consist of: (1) The RPS is structured systematically, (2) RPS is arranged sequentially for each meeting for one semester. The results of the RPS validation by 5 validators can be seen in Figure 4. Figure 4 shows that for each aspect of the RPS assessment, all validators gave ratings good and very good. Based on the development achievement indicators, it can be concluded that the video presentation based e-learning RPS in the introductory education course is said to be valid.

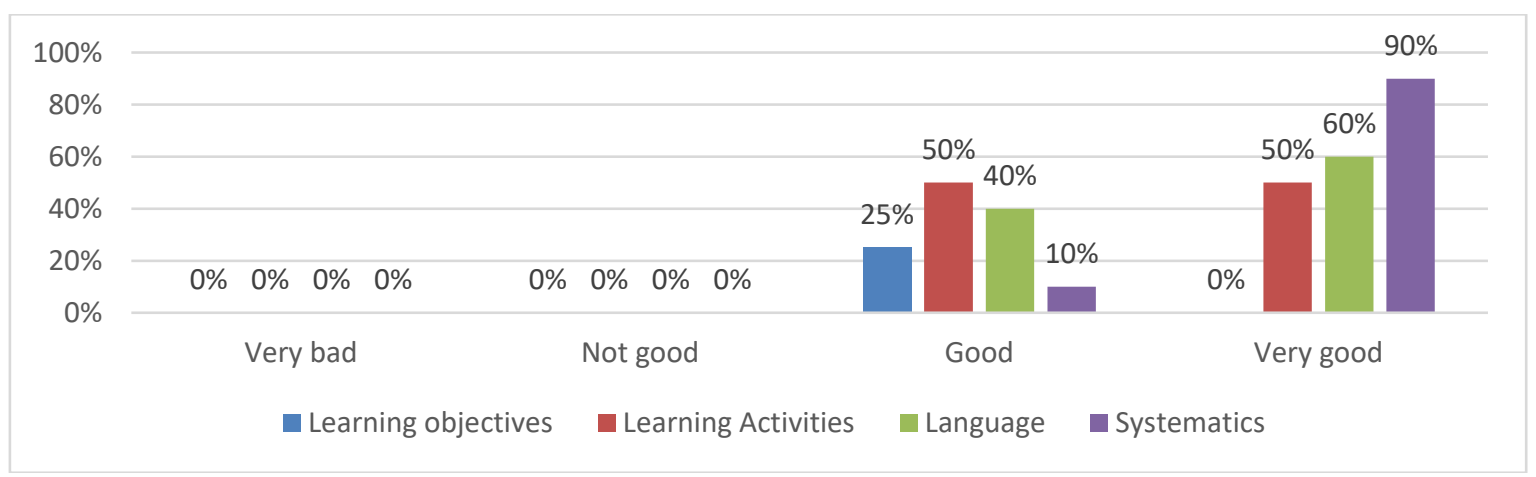

Figure 4. RPS Validation Results 
To find out the validity of the LMS introductory education setting, an assessment was carried out on aspects including: format, language, learning activities and systematics. The aspect of format consist of: (1) Clarity of material distribution, (2) Has charm, (3) Room/layout arrangement, (4) Font size and type accordingly. The aspect of language consist of: (1) Grammatical correctness, (2) Suitability of sentences with student abilities, (3) Simplicity of sentence structure, (4) The sentence does not contain a double meaning, (5) Clarity and accuracy of the language used. The aspect of learning activities consist of: (1) Learning topics according to the RPS, (2) Activities on the LMS according to RPS, (3) Activities on the LMS according to the method chosen, (4) Activities in the LMS are in accordance with the video presentation, (5) Each activity is given a description for each meeting. The aspect of systematics consist of: (1) Activities on the LMS are systematic, (2) Activities in the LMS are sorted according to learning meetings for 1 semester. The results of validating the LMS settings by 5 validators can be seen in Figure 5 .

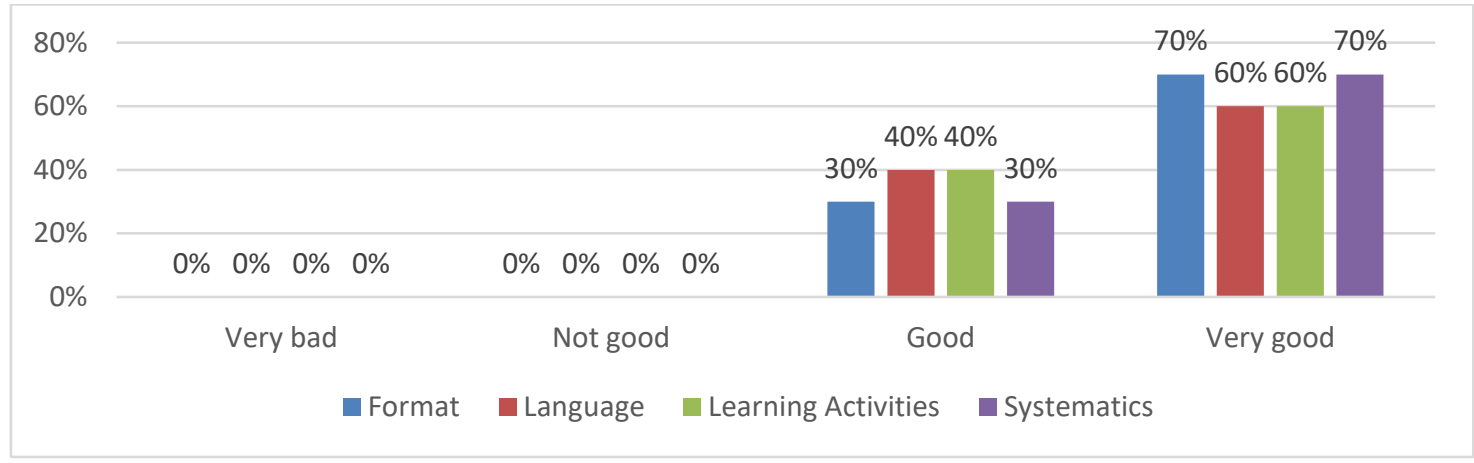

Figure 5. Validation Results of LMS Settings

From Figure 5, it can be seen that all validators gave good and very good ratings for every aspect of the LMS setting assessment. Based on the indicators of development achievement, it can be concluded that the setting of LMS e-learning based on video presentation in the introductory education course is said to be valid. To determine the validity of the introductory education video presentation, an assessment was carried out on aspects including: format, language and illustrations. The aspect of format consist of: (1) The clarity of the material presented, (2) Has charm, (3) Compatibility between text and illustrations, (4) Room/layout arrangement, (5) Type and size of letters for presentation of material. The aspect of language consist of: (1) Grammatical correctness, (2) Suitability of sentences with student abilities, (3) Simplicity of sentence structure, (4) Encourage interest in watching videos, (5) The sentence does not contain a double meaning, (6) Clarity and accuracy of the language used The language used is communicative. The aspect of illustration consist of: (1) Illustration support to clarify concepts on the video, (2) Provide visual stimulation, (3) Has a clear appearance, (4) Easy to understand. The results of the validation of the presentation video by 5 validators can be seen in Figure 6 .

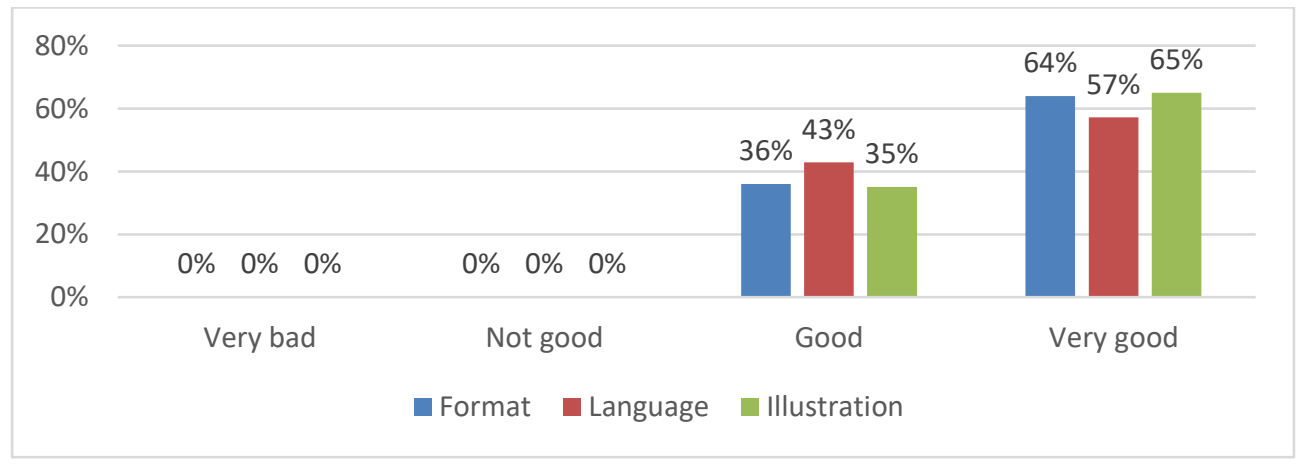

Figure 6. Results of Video Presentation Validation 
From Figure 6, it can be seen that all the validators gave good and very good ratings for every aspect of the assessment of the LMS setting. Based on the indicators of development achievement, it can be concluded that the setting of LMS e-learning based on video presentation in the introductory education course is said to be valid. To find out the practicality of the e-learning tool based on video presentations in the introductory education course, it was done by providing a response questionnaire to students. The statements in the student response questionnaire include 3 aspects, namely the implementation of lectures, the use of e-learning, and the suitability of teaching materials. The lecture implementation aspect includes the following statements: (1) at the beginning of the lecture the lecturer submits the lecture contract (course material, evaluation, and reference books), (2) the presentation of the lecture is easy for students to accept and understand, (3) the lecturer is able to motivate students to study harder. Aspects of using e-learning include the following statements: (1) e-learning is used to share lecture material in the form of pdf, ppt, video, or website links, (2) e-learning can be used to conduct virtual face-to-face learning with web meetings, (3) assignments from lecturers and answers from students are uploaded in elearning, discussions between lecturers and students or students with other students are carried out by e-learning, (4) the lecturer gives a test using one / more of the features: multiple choice, true-false, matching, short answer, and others. Aspects of the suitability of teaching materials include the following statements: (1) the course material is in accordance with the RPS, (2) the material is delivered through an interesting video and is in accordance with the RPS, (3) the test questions are appropriate and relevant to the lecture material.

The students gave positive responses to small trials for the aspects of lecture implementation, use of e-learning, and the suitability of teaching materials respectively by $97 \% ; 97.89 \%$; $98.33 \%$. In the broad trial, students gave a positive response to the aspects of the implementation of lectures, the use of e-learning, and the suitability of teaching materials respectively by $98 \% ; 98.2 \% ; 99 \%$. From the results of this analysis, the students as a whole gave a positive response to the small trial of $97.68 \%$ and the broad trial of $98.32 \%$. The effectiveness of the development of e-learning based on video presentations in this introductory education course is seen from the student learning outcomes in the aspects of attitudes, knowledge skills, and skills. The aspect of attitude that is assessed is the activeness and responsibility of students in following video-based e-learning lectures. The indicators of activeness used for assessment in this study include: students respond to lecturers 'questions, students ask if there is material that is not understood, students respond to other students' opinions, students participate in learning either synchronously or asynchronously. The responsibility indicators used for assessment in this study include: students take virtual/synchronous face-to-face learning, students take asynchronous learning, students collect assignments, students take tests.

The skill aspect is assessed by the student's ability to present material via video which is presented in group discussion forums. Indicators of skills used for assessment in this study include: students can upload video presentations on the LMS (discussion forum), students can design video presentations, students can deliver material orally through video presentations, students can deliver material in writing through video presentations. The knowledge aspect is assessed through an essay test that is included in the e-LMA. The essay test is designed based on the learning outcomes of the introductory education course. The small trial the achievement of student learning outcomes for the aspects of attitudes, skills and knowledge respectively was $85.36 \% ; 82.93 \% ; 80.48 \%$ of students who get a score of more than or equal to 75 . In the broad trial the achievement of student learning outcomes for the aspects of attitudes, skills and knowledge was successively $90.24 \% ; 87.80 \% ; 82.93 \%$ of students who scored more than or equal to 75 . From the results of this analysis, the average value of student learning outcomes on the small trial was $82.92 \%$ and the broad trial was $86.99 \%$ of students who got more than or equal to 75 . This indicates that the e-learning based on video presentations that has been developed has the criteria of being effective. Through the development of e-learning based on video presentations, student teacher candidates can develop their competence which can be seen in the attitudes, knowledge and skills of students in delivering material through online presentations. 


\section{Discussion}

Online learning tools designed to suit the characteristics of learners, namely students who are prospective mathematics teachers. Prospective mathematics teacher students at UNIPMA are students from both general and vocational high schools. The majority of students who are taking introductory education courses are around 19-21 years of age who are at the stage of formal operational cognitive development. For prospective mathematics teacher students, mastery of educational introductory material is important as a provision to become teachers in the future. Teacher is a profession which is not an ordinary job but must have competence (Husain et al., 2015; Rusdin, 2018; Tondeur et al., 2019). However, most students feel bored and bored with the material in introductory education courses because they think it is memorization material. This causes student learning outcomes to be less than optimal in terms of attitudes, skills and knowledge. Introductory education is a compulsory deprogram subject for prospective teachers including prospective mathematics teachers. In higher education institutions that produce mathematics teacher candidates, the curriculum used determines courses that support pedagodic and professional competences (Pratama \& Retnawati, 2018; Tanudjaya \& Doorman, 2020). Introductory education courses are courses that support pedagogical competences. This pedagogic competence is important to provide to student teacher candidates because pedagogical competence is a basic ability that professional teachers must have (Lubis, 2018). This competence is also in line with experts regarding the importance of pedagogic knowledge and content for teachers and prospective teachers (Bukova-Güzel, 2010; Kleickmann et al., 2013). An important introductory education course is given to prospective teachers because the learning outcomes contain learning theories and learning as basic knowledge that must be mastered by prospective mathematics teachers.

The results of preliminary research show that so far the majority of students who are prospective teachers of mathematics education feel bored when learning introductory education because they contain theories which according to him are memorization material (Fitra Surya, 2017; Lestari, 2015; Mustika \& Riastini, 2017). Not to mention that the Covid-19 pandemic requires teachers / lecturers to design learning devices that are not as usual. Learning must be done remotely to minimize the spread of Covid-19. This is also in line with the policy of the minister of education and culture in Indonesia so that learning is carried out from home, from basic to tertiary education (Aji, 2020; Dzalila et al., 2020; Yousfi et al., 2021). To solve these problems ultimately requires learning innovation. The prototyping results obtained an e-learning innovation design based on video presentations in the introductory education course. The design includes: RPS, LMS settings and video presentations tailored to the learning outcomes of introductory education courses. The design of the RPS is carried out by adjusting the learning settings, namely online. The design of the RPS, which includes course descriptions, course learning outcomes, final abilities planned to achieve learning outcomes, study materials (learning materials), learning methods, learning experiences, time allocation, assessment, resources study (Desnita \& Susanti, 2017; Krisdiana et al., 2018). LMS settings and presentation videos are designed according to RPS. Suitability between learning devices must be considered in designing learning devices. The development of e-learning based on video presentations in the introductory education course can be said to be practical. The learning device is practical if students give a positive response of more than $70 \%$ (Trilaksono et al., 2018). Attitude assessment includes student activeness and responsibility in following video-based elearning presentations on introductory education courses. Students respond to questions from other lecturers/students, ask questions if there is material that has not been understood, and follow learning both synchronously and asynchronously (Putra \& Purwasih, 2016; Tere et al., 2020).

Assessment of the skills aspect through e-learning based on video presentations in this introductory education course during the Covid-19 pandemic provides new experiences for prospective teacher students who are part of technology pedagogical and content knowledge (TPACK). TPACK is a type of knowledge that teachers need to teach effectively with technology. This is important for future teacher candidates (Reyes et al., 2017). 
Assessment of the pedagogical knowledge aspect through e-learning based on video presentations in this introductory education course during the Covid-19 pandemic provides experience to prospective mathematics teachers as provisions to become professional teachers. The pedagogical knowledge taught to students through introductory education courses includes educational theories, problems and future educational developments. This is very important given because it is part of the knowledge that must be possessed by prospective teachers, namely pedagogical content knowledge and also TPACK (BukovaGüzel, 2010; Cantürk-günhan et al., 2012; Kilic, 2013; Murtafiah \& Lukitasari, 2019). The development of e-learning based on video presentations in this introductory education course is feasible because it meets the criteria of being valid, practical, and effective. These results are in line with several studies which state that a learning device is said to be feasible if it has valid, practical, and effective criteria (Ariska et al., 2018; Krisdiana et al., 2018; Murtafiah, 2010; Samo et al., 2017).

This research has never been conducted before, because in this study, e-learning based on video presentations was developed to improve attitudes, knowledge and pedagogical knowledge of prospective teacher. This can be seen in previous research that has been conducted regarding e-learning for university students (Irfan et al., 2020; Sulistyaningsih et al., 2018). The learning outcomes of students, but revealed the challenges faced by lecturers in universities in carrying out learning during the Covid-19 pandemic (Irfan et al., 2020). The development of e-learning based on video presentations can be used to enhance attitudes, skills, and pedagogical knowledge, and also TPACK for prospective mathematics teacher students in the introductory education course. Attitudes that are enhanced through the development of video presentation-based learning tools are the attitudes of students in online learning activities. Student skills can be built through the development of video presentation-based learning, such as skills in designing presentations using powerpoints uploaded on YouTube. Pedagogic knowledge that is built through the development of video presentation-based learning is knowledge about educational material that must be delivered by students through online presentations. This research is limited to the development of e-learning based on video presentation to improve the attitudes, knowledge and pedagogic knowledge of prospective teacher students in the introductory education course. Development is only carried out in the mathematics education study program at Universitas PGRI Madiun. As for the suggestions that can be conveyed, for further research, it can be developed e-learning based on video presentations in other courses to expand the achievement of student learning outcomes such as other special knowledge and skills in utilizing technology.

\section{Conclusions and Suggestions}

All devices developed have valid criteria based on the results of validation. Students gave positive responses to the small and broad trials so that the tools developed are included in the practical criteria. The assessment of learning outcomes in the aspects of attitudes, skills and knowledge had an average completeness on the small and broad trials so that the equipment used is included in the effective criteria.

\section{References}

Aji, R. H. S. (2020). Dampak Covid-19 pada Pendidikan di Indonesia: Sekolah, Keterampilan, dan Proses Pembelajaran. Jurnal Sosial Dan Budaya Syar-I, 7(5). https://doi.org/10.15408/sjsbs.v7i5.15314.

Ali, W. (2020). Online and Remote Learning in Higher Education Institutes: A Necessity in light of COVID-19 Pandemic. Higher Education Studies, 10(3), 16-25. https://doi.org/10.5539/hes.v10n3p16.

Ambussaidi, I., \& Yang, Y.-F. (2019). The Impact of Mathematics Teacher Quality on Student Achievement in Oman and Taiwan. International Journal of Education and Learning, 1(2), 50-62. https://doi.org/10.31763/ijele.v1i2.39. 
Ariska, M. D., Darmadi, \& Murtafiah, W. (2018). Pengembangan Media Pembelajaran Menggunakan Adobe Flash Berbasis Metakognisi Untuk Meningkatkan Motivasi Belajar Matematika. Edumatica, 08(01 April), 83-97. https://doi.org/10.22437/edumatica.v8i01.4622.

Baber, H. (2020). Determinants of Students 'Perceived Learning Outcome and Satisfaction in Online Learning during the Pandemic of COVID19. Journal of Education and ELearning Research, 7(3), 285-292. https://doi.org/10.20448/journal.509.2020.73.285.292.

Backfisch, I., Lachner, A., Hische, C., Loose, F., \& Scheiter, K. (2020). Professional knowledge or motivation? Investigating the role of teachers' expertise on the quality of technology-enhanced lesson plans. Learning and Instruction, 66. https://doi.org/10.1016/j.learninstruc.2019.101300.

Basilaia, G., \& Kvavadze, D. (2020). Transition to Online Education in Schools during a SARS-CoV-2 Coronavirus ( COVID-19) Pandemic in Georgia. Pedagogical Research, 5(4). https://doi.org/10.29333/pr/7937.

Batubara, H. H., \& Batubara, D. S. (2020). Penggunaan Video Tutorial untuk Mendukung Pembelajaran Daring di Masa Pandemi Virus Corona. Jurnal Madrasah Ibtidaiyah, 5(2). https://doi.org/10. 31602/muallimuna.v5i2.2950.

Buana, D. R. (2020). Analisis Perilaku Masyarakat Indonesia dalam Menghadapi Pandemi Virus Corona (Covid-19) dan Kiat Menjaga Kesejahteraan Jiwa. SALAM: Jurnal Sosial Dan Budaya Syar-I, 7(3). https://doi.org/10.15408/sjsbs.v7i3.15082.

Bukova-Güzel, E. (2010). An investigation of pre-service mathematics teachers' pedagogical content knowledge, using solid objects. Scientific Research and Essays, 5(August 2010), 1872-1880.

Cahyadi, A. (2020). Covid-19 Outbreak and New Normal Teaching in Higher Education: Empirical Resolve from Islamic Universities in Indonesia. Dinamika IImu, 20(2), 255266. https://doi.org/10.21093/di.v20i2.2545.

Cantürk-günhan, B., Bukova-güzel, E., \& Özgür, Z. (2012). The prospective mathematics teachers 'thought processes and views about using problem-based learning in statistics education. International Journal of Mathematical Education in Science and Technology, 43(November 2014), 37-41. https://doi.org/10.1080/0020739X.2011.592611.

Desnita, D., \& Susanti, D. (2017). Science Process Skills-Based Integrated Instructional Materials to Improve Student Competence Physics Education Prepares Learning Plans on Teaching Skills Lectures. Jurnal Penelitian \& Pengembangan Pendidikan Fisika, 3(1), 35. https://doi.org/10.21009/1.03105.

Dewantara, J. A., \& Nurgiansah, T. H. (2020). Efektivitas Pembelajaran Daring di Masa Pandemi COVID 19 Bagi Mahasiswa Universitas PGRI Yogyakarta. Jurnal Basicedu, 5(1), 367-375. https://doi.org/10.31004/basicedu.v5i1.669.

Dhawan, S. (2020). Online Learning: A Panacea in the Time of COVID-19 Crisis. Journal of Educational Technology Systems, 49(1), 5-22. https://doi.org/10.1177/0047239520934018.

Dzalila, L., Ananda, A., \& Zuhri, S. (2020). Pengaruh Pembelajaran Daring Pada Masa Pandemi Covid-19 Terhadap Tingkat Pemahaman Belajar Mahasiswa. Jurnal Signal, 8(2), 203. https://doi.org/10.33603/signal.v8i2.3518.

Eryadini, N., Nafisah, D., Sidi, A., \& Buana-lamongan, U. P. A. (2020). Psikologi Belajar Dalam Penerapan Distance Learning. Jurnal Pendidikan Dan Pengabdian Masyarakat, 3(3), 163-168. https://doi.org/10.31004/basicedu.v5i4.1051.

Fitra Surya, Y. (2017). Penerapan Model Pembelajaran Problem Based Learning untuk Meningkatkan Hasil Belajar Matematika Siswa Kelas IV SDN 016 Langgini Kabupaten Kampar. Jurnal Pendidikan Matematika, 1(1), 38-53. https://doi.org/10.31004/cendekia.v1i1.7.

Hillmayr, D., Ziernwald, L., Reinhold, F., Hofer, S. I., \& Reiss, K. M. (2020). The potential of digital tools to enhance mathematics and science learning in secondary schools: A context-specific meta-analysis. Computers and Education, 153(September 2018), 
103897. https://doi.org/10.1016/j.compedu.2020.103897.

Hobri. (2010). Metodologi Penelitian Pengembangan: Aplikasi Pada Penelitian Pendidikan Matematika. Pena Salsabila.

Husain, Bahiyah, Wahab, \& Jantan, J. (2015). Determining Teaching Effectiveness for Physical Education Teacher-Review under Responsibility of GLTR International SDN. Berhad. Procedia-Social and Behavioral Sciences, 172, 733-740. https://doi.org/10.1016/j.sbspro.2015.01.426.

Irfan, M., Kusumaningrum, B., Yulia, Y., Widodo, S. A., Info, A., Learning, O., \& Learning, M. (2020). Challenges During the Pandemic: Use of E-Learning in Mathematics Learning in Higher Education. Infinity: Journal of Mathematics Education, 9(2), 147-158. https://doi.org/10.22460/infinity.v9i2.p147-158.

Kadafi, A., Alfaiz, A., Ramli, M., Asri, D. N., \& Finayanti, J. (2021). The impact of islamic counseling intervention towards students' mindfulness and anxiety during the covid19 pandemic. Islamic Guidance and Counseling Journal, 4(1), 55-66. https://doi.org/10.25217/igcj.v4i1.1018.

Kilic, C. (2013). Turkish Primary School Teachers' Opinions about Problem Posing Applications: Students, the Mathematics Curriculum and Mathematics Textbooks. Australian Journal of Teacher Education, 38(5), 143-155. https://doi.org/10.14221/ajte.2013v38n5.10.

Kleickmann, T., Richter, D., Kunter, M., Elsner, J., Besser, M., Krauss, S., \& Baumert, J. (2013). Teachers' Content Knowledge and Pedagogical Content Knowledge: The Role of Structural Differences in Teacher Education. Journal of Teacher Education, 64(1), 90-106. https://doi.org/10.1177/0022487112460398.

Krisdiana, I., Masfingatin, T., \& Murtafiah, W. (2018). The Development of Research-Based Learning Materials with Problem Solving and Problem Posing Oriented of Mathematics Statistics. Al-Jabar: Jurnal Pendidikan Matematika, 9(2), 147-160. https://doi.org/10.24042/ajpm.v9i2.2961.

Lestari, I. (2015). Pengaruh Waktu Belajar dan Minat Belajar terhadap Hasil Belajar Matematika. Formatif: Jurnal IImiah Pendidikan MIPA, 3(2), 115-125. https://doi.org/10.30998/formatif.v3i2.118.

Logan, R. M., Johnson, C. E., \& Worsham, J. W. (2021). Development of an E-learning Module to Facilitate Student Learning and Outcomes. Teaching and Learning in Nursing, 16(2), 139-142. https://doi.org/10.1016/j.teln.2020.10.007.

Lubis, H. (2018). Kompetensi Pedagogik Guru Profesional. Best Journal (Biology Education, Sains and Technology), 1(2), 16-19. https://doi.org/10.30743/best.v1i2.788.

Mayang Ayu Sunami, \& Aslam. (2021). Pengaruh Penggunaan Media Pembelajaran Video Animasi Berbasis Zoom Meeting terhadap Minat dan Hasil Belajar IPA Siswa Sekolah Dasar. Jurnal Basicedu, 5(4), 1-9. https://doi.org/10.31004/basicedu.v5i4.1129.

Meilantifa, M., \& Budiarto, M. T. (2018). The development of teaching material: Rigorous mathematical thinking in a geometry classroom. Journal of Physics: Conference Series, 1088, 4-9. https://doi.org/10.1088/1742-6596/1088/1/012062.

Mpungose, C. B. (2021). Lecturers' reflections on use of Zoom video conferencing technology for e-learning at a South African university in the context of coronavirus. African Identities. https://doi.org/10.1080/14725843.2021.1902268.

Murtafiah, W. (2010). Pengembangan Lembar Kegiatan Siswa dengan Pembelajaran Matematika Realistik Berbasis Life Skills pada Materi Bangun Ruang Sisi Datar di Kelas VIII SMP. Jurnal Pendidikan MIPA, 2(1), 15-36. https://doi.org/10.24014/juring.v4i3.14024.

Murtafiah, W., \& Lukitasari, M. (2019). Developing Pedagogical Content Knowledge of Mathematics Pre-Service Teacher through Microteaching Lesson Study. Jurnal Pendidikan Matematika, 13(2), 201-218. https://doi.org/10.22342/jpm.13.2.7663.201218.

Mustika, I. K. A., \& Riastini, P. N. (2017). Pengaruh Model Polya Terhadap Kemampuan Pemecahan Masalah Matematika Siswa Kelas V SD. International Journal of Community Service Learning Universitas Pendidikan Ganesha, 1(1), 31-38. 
https://doi.org/10.23887/ijee.v1i3.11887.

Plomp, T. (2010). Educational Design Research: an Introduction. In T. Plomp \& N. Nieveen (Eds.), An Introduction to Educational Design Research (3rd print, pp. 9-36).

Pratama, G. S., \& Retnawati, H. (2018). Urgency of Higher Order Thinking Skills (HOTS) Content Analysis in Mathematics Textbook. Journal of Physics: Conference Series, 1097(1). https://doi.org/10.1088/1742-6596/1097/1/012147.

Prawiyogi, A. G., Purwanugraha, A., Fakhry, G., \& Firmansyah, M. (2020). Efektifitas Pembelajaran Jarak Jauh Terhadap Pembelajaran Peserta didik di SDIT Purwakarta. JPD: Jurnal Pendidikan Dasar, 11(1). https://doi.org/10.21009/10.21009/JPD.081.

Prehanto, A., Aprily, N. M., Merliana, A., \& Nurhazanah, M. (2021). Video Pembelajaran Interaktif-Animatif sebagai Media Pembelajaran IPS SD Kelas Tinggi di Masa Pandemi Covid 19. Indonesian Journal of Primary Education, 5(1), 32-38. https://doi.org/10.17509/ijpe.v5i1.33696.

Putra, H. D., \& Purwasih, R. (2016). Meningkatkan Prestasi Belajar dan Keaktifan Mahasiswa melalui Project Based Learning. Jurnal IImiah UPT P2M STKIP Siliwangi, 3(1), 128-136. https://doi.org/10.22460/p2m.v2i2p128-136.156.

Reyes, V. C., Reading, C., Doyle, H., \& Gregory, S. (2017). Integrating ICT into teacher education programs from a TPACK perspective: Exploring perceptions of university lecturers. Computers and Education, 115, 1-19. https://doi.org/10.1016/j.compedu.2017.07.009.

Rusdin, N. M. (2018). Teachers' Readiness in Implementing 21st Century Learning. International Journal of Academic Research in Business and Social Sciences, 8(4), 1271-1284. https://doi.org/10.6007/IJARBSS/v8-i4/4270.

Sadikin, A., \& Hamidah, A. (2020). Pembelajaran Daring di Tengah Wabah Covid-19. Biodik, 6(2), 109-119. https://doi.org/10.22437/bio.v6i2.9759.

Saiboon, I. M., MSurg, Nurmaimun, Noriani, Shamsuddin, N. S., \& Johar, M. (2021). Effectiveness of Self-Directed Small-Group-Learning Against Self-Directed IndividualLearning Using Self-Instructional-Video in Performing Critical Emergency Procedures Among Medical Students in Malaysia: A Single-Blinded Randomized Controlled Study. Clinical Simulation in Nursing, 56(1). https://doi.org/10.1016/j.ecns.2021.02.006.

Samo, D. D., Darhim, D., \& Kartasasmita, B. (2017). Developing Contextual Mathematical Thinking Learning Model to Enhance Higher-Order Thinking Ability for Middle School $\begin{array}{llll}\text { Students. International Education } & \text { Studies, }\end{array}$ https://doi.org/10.5539/ies.v10n12p17.

Sanusi, Murtafiah, W., \& Krisdiana, I. (2016). Pengembangan Bahan Ajar Microteaching Untuk Melatihkan Kompetensi Pedagogik Yang Mengintegrasikan Tik. Jurnal Lppm, 4(1 Januari). https://doi.org/10.25273/jems.v2i2.228.

Shah, K., Arfan, M., Mahariq, I., Ahmadian, A., Salahshour, S., \& Ferrara, M. (2020). FractalFractional Mathematical Model Addressing the Situation of Corona Virus in Pakistan. Results in Physics, 19, 103560. https://doi.org/10.1016/j.rinp.2020.103560.

Subarkah, M. A., \& Salim, A. (2021). "Analisis Kesulitan Belajar Peserta Didik Dalam Pembelajaran Jarak Jauh (Pjj) Di Tengah Pandemi Covid-19". Rausyan Fikr: Jurnal Pemikiran Dan Pencerahan, 17(1). https://doi.org/10.31000/rf.v17i1.4184.

Sulistyaningsih, D., Purnomo, P., \& Aziz, A. (2018). Development of Learning Design for Mathematics Manipulatives Learning based on E-learning and Character Building. International Electronic Journal of Mathematics Education, 14(1), 197-205. https://doi.org/10.29333/iejme/3996.

Supriadi, S. (2020). Implementation Of Demonstration Method To Improve Teacher Knowledge Of Adiwiyata School. Jurnal Pajar (Pendidikan Dan Pengajaran), 4(1). https://doi.org/10.33578/pjr.v4i1.7928.

Tamboto, H., Tambingon, H. N., Lengkong, J. S. ., \& Rotty, V. N. J. (2021). The Involvement of Students' Parents in Organizing the Learning from Home at Elementary Schools in Tomohon City. Asia Pacific Journal of Management and Education, 4(1), 35-51. https://doi.org/10.32535/apjme.v4i1.1044. 
Tanudjaya, C. P., \& Doorman, M. (2020). Examining higher order thinking in Indonesian lower secondary mathematics classrooms. Journal on Mathematics Education, 11(2), 277-300. https://doi.org/10.22342/jme.11.2.11000.277-300.

Teng, M. F. (2019). The effects of video caption types and advance organizers on incidental L2 collocation learning. Computers \& Education, 142. https://doi.org/10.1016/j.compedu.2019.103655.

Tere, T., Bayu Seta, H., Nizar Hidayanto, A., \& Abidin, Z. (2020). Variables Affecting ELearning Services Quality in Indonesian Higher Education: Students' Perspectives. Journal of Information Technology Education: Research, 19, 259-286. https://doi.org/10.28945/4489.

Tondeur, J., Scherer, R., Baran, E., Siddiq, F., Valtonen, T., \& Sointu, E. (2019). Teacher educators as gatekeepers: Preparing the next generation of teachers for technology integration in education. British Journal of Educational Technology, 50(3), 11891209. https://doi.org/10.1111/bjet.12748.

Trilaksono, D., Darmadi, D., \& Murtafi'ah, W. (2018). Pengembangan Media Pembelajaran Matematika Menggunakan Adobe Flash Professional Berbasis Literasi Untuk Meningkatkan Kreativitas Siswa. AKSIOMA: Jurnal Program Studi Pendidikan Matematika, 7(2), 180. https://doi.org/10.24127/ajpm.v7i2.1428.

Wu, S.-C. (Angel), \& Chang, Y.-L. (Aldy). (2015). Advancing Kindergarten Teachers' Knowledge and Capabilities of Differentiated Instruction Associated with Implementation of Thematic Integrated Curriculum. Procedia - Social and Behavioral Sciences, 177. https://doi.org/10.1016/j.sbspro.2015.02.404.

Wu, W., \& Plakhtii, A. (2021). E-Learning Based on Cloud Computing. International Journal of Emerging Technologies in Learning (IJET), 16(10), 4. https://doi.org/10.3991/ijet.v16i10.18579.

Yaniawati, R. P. (2013). E-Learning to Improve Higher Order Thinking Skills ( HOTS ) of Students. Journal of Education and Learning, 7(2), 109-120. https://doi.org/10.11591/edulearn.v7i2.225.

Yendrita, \& Syafitri. (2019). Pengaruh Penggunaan Media Video Pembelajaran Terhadap Hasil Belajar Biologi. Jurnal Pendidikan Biologi Dan Sains, 2(1). https://doi.org/10.31539/bioedusains. v2i1.620.

Yousfi, M., Zaied, Y. Ben, Cheikh, N. Ben, Lahouel, B. Ben, \& Bouzgarrou, H. (2021). Effects of the COVID-19 pandemic on the US stock market and uncertainty: A comparative assessment between the first and second waves. Technological Forecasting and Social Change, 167. https://doi.org/10.1016/j.techfore.2021.120710.

Yudiawan, A. (2020). Belajar Bersama COVID 19: Evaluasi Pembelajaran Daring Era Pandemi di Perguruan Tinggi Keagamaan Islam Negeri, Papua Barat. Al-Fikr : Jurnal Pendidikan Islam, 6(1). https://doi.org/10.32489/alfikr.v6i1.64.

Yulia. (2020). Online Learning to Prevent the Spread of Pandemic Corona Virus in Indonesia. ETERNAL (English Teaching Journal), https://doi.org/10.26877/eternal.v11i1.6068. 